\title{
MENGENAL BUDAYA SUKU BUGIS
}

\author{
SYAMSU RIJAL AS \\ Fakultas Hukum Institut IImu Sosial dan Bisnis Andi Sapada \\ Email : Syam50240@gmail.com
}

Latar Belakang

Indonesia sebagai negara kepulauan terkenal akan keanekaragaman suku, bahasa, agama, dan budaya. Kebudayaan setiap daerah-daerah terhitung menjadi kesatuan kebudayaan nasional yang tertuang dalam Undang-Undang Dasar 1945 pasal 32. Kebudayaan daerah menjadi salah satu unsur yang penting dalam membangun kehidupan bangsa Indonesia, yang mana kebudayaan tersebut merupakan jati diri bangsa. Kebudayaan ialah keseluruhan dari kelakuan dan hasil kelakuan manusia yang teratur oleh tata-kelakuan yang harus didapatnya dengan belajar dan yang semuanya tersusun dalam kehidupan bermasyarakat.

Sulawesi Selatan adalah salah satu dari 34 propinsi dalam Negara Kesatuan Republik Indonesia. Di provinsi ini terdapat empat suku bangsa utama yaitu, Toraja, Makassar, Bugis dan Mandar. Suku Bugis adalah salah satu suku yang terbesar yang mendiami daerah Sulawesi Selatan. "Suku bangsa Bugis terutama mendiami kabupaten- kabupaten Bone, Wajo, Soppeng, Sinjai, Bulukumba, Barru, Pare- Pare, Sidrap, Pinrang dan Luwu. Sebahagian penduduk Pangkajene dan Maros, sebagai daerah perbatasan antara negeri-negeri orang Bugis - Makassar, adalah orang Bugis atau orang Makassar. "Bugis adalah suku yang tergolong ke dalam suku-suku Melayu Deutero. Kata "Bugis" berasal dari kata To Ugi, yang berarti orang Bugis. (Shintia Maria Kapojos dan Hengki Wijaya)

Menarik untuk dipelajari etnografi kebudayaan suku bugis karena memiliki ciri yang khas. "Mereka adalah contoh yang jarang terdapat di wilayah Nusantara. Mereka mampu mendirikan kerajaan- kerajaan yang sama sekali tidak mengandung pengaruh India, dan tanpa mendirikan kota sebagai pusat aktivitas mereka. Perpindahan besarbesaran orang "Bugis" ke luar kampungnya di Sulawesi Selatan di mulai pada paruh 
baya ke-17 dan ke-18. Hari ini orang Bugis telahtersebar di segala kawasan. Di seluruh wilayah Nusantara dari Semenanjung Melayu dan Singapura hingga pesisir barat Papua, dari Filipina Selatan daan Kalimantan Utara hingga usa Tenggara dapat dijumpai orang Bugis yang sibuk dengan aktivitas pelayaran, perdagangan, pertanian, pembukaan lahan perkebunan di hutan, atau pekerjaan apa saja yang sesuai. Meskipun telah tersebar di mana saja, identitas suku ini tetap terlihat di mana pun mereka tinggal. Orang Bugis ternyata tetap mampu mempertahankan identitas "kebugisan" mereka.

\section{Metode Penelitian}

Penelitian ini menggunakan metode normatif yang mana metode ini menggunakan pendekatan historis dan memahami tentang budaya suku bugis yang meliputi tentang sistem kekerabatan dan perkawiinan.

\section{Analisis dan Pembahasan}

Orang Bugis sendiri mengenal masa lampau mereka melaluidua macam manuskrip anonim yakni mitos/epos dan teks sejarah/kronik. Jenis pertama berwujud sebuah karya sastra besar berisi cerita bersyair, yang dinamakan Sure' Galigo oleh orang Bugis. Jenis kedua, adalah sejumlah besar kronik orang Bugis, Makassar dan Mandar. Sure' Galigo merupakan bagian yang tidak terpisahkan dari identitas kebudayaan Bugis. Naskah La Galigo bercerita tentang ratusan keturunan dewa yang hidup pada masa selama enam generasi turun-temurun pada berbagai kerajaan di Sulawesi Selatan.

\section{A. Rahman Rahim Menuliskan}

“Sure’ Galigo menceritakan tentang awal mula dihuninya negeri Bugis, ketika Batara Guru dari Botinglangi' (dunia atas) bertemu di Tana Luwu dengan We'Nyelli timo dari Buri'liung

(dunia bawah). Simpuru'siang di Luwu, Sengingridi di Bone, Petta Sekkanyili di Soppeng, puteri Temmalate di Gowa, semuanya adalah Tomanurung yang membentuk masyarakat

Bugis-Makassar. 
Naskah yang bersyair tersebut ditulis dalam bahasa Bugis kuno dengan bahasa sastra tinggi dan oleh masyarakat Bugis dipercayai sebagai kitab sakral." ${ }^{12}$ Selain pos/mitos, kronik/teks sejarah kebudayaan bugis dapat ditemukan dalam sejumlah lontara.

Lontara adalah sesuai dengan kata lontar (Jawa/Melayu), yang merupakan transposisi kata rontal, yang merupakan kombinasi kata ron, daun, dan tal. Tal adalah pohon Borassus flabelliformis yang daunnya dapat dipakai untuk menulis. Lontara pertama-tama berarti daun lontar, dan dalam arti luas berarti setiap karya tulis."13 Dalam lontara memuat begitu macam informasi yang penting." Lontara berisi catatan rinci mengenai silsilah keluarga bangsawan, wilayah kerajaan, catatan harian, serta berbagai macam informasi lain seperti, daftar kerajaan-kerajaan, naskah perjanjian dengan kerajaan lain atau persetujuan yang telah diadakan intra-kerajaan sendiri antara penguasa dan rakyat.

\section{Sistem Kekerabatan}

Dalam kehidupan masyarakat yang masih sederhana atau paling tidak kelompok yang memiliki jumlah anggota terbatas, biasanya hubungan antara masing anggotanya saling mengenal secara mendalam. Yang menjadi dasar kekuatan ikatan kelompok semacam ini adalah sistem kekerabatan. Lestari (2009) dalam Ardhani menjelaskan sistem kekerabatan masyarakat Bugis disebut dengan assiajingeng yang tergolong parental, yaitu sistem kekerabatan yang mengikuti pergaulan hidup dari ayah maupun dari pihak ibu atau garis keturunan berdasarkan kedua orang tua. Sistem kekerabatan merupakan aspek yang sangat penting dalam masyarakat.

Pengetahuan mendalam tentang prinsip-prinsip kekerabatan sangat Diperlukan guna memahami apa yang mendasari berbagai aspek kehidupan masyarakat yang dianggap paling penting oleh orang Bugis dan saling berkaitan dalam membentuk tatanan sosial mereka. Pada dasarnya, sistem kekerabatan itu, berkembang dari suatu kelompok keluarga batih (Bugis: sianangmaranak). Sebagai keluarga batih, mereka terdiri atas ayah, ibu dan anak-anak dari ayah ibu tersebut yang hidup dalam sebuah rumah tangga. Sebagaimana umumnya masyarakat 
Austronesia, khususnya orang-orang Nusantara seperti Melayu, Jawa, Kalimantan, Filipina, dan orang Bugis pun menganut sistem kekerabatan bilateral. Kelompok kekerabatan bilateral seseorang ditelusuri melalui garis keturunan dari pihak ayah maupun ibu." ${ }^{19}$ Namun demikian dalam keluarga Bugis, dalam sebuah rumah tangga tidak hanya terdiri dari anak dari ayah dan ibu, tetapi juga terdapat anggota keluarga yang lainnya, seperti sepupu, keponakan dari suami atau istri, nenek dan kakek.

Terminologi kekerabatan masyarakat Bugis cukup sederhana dan tergolong sistem kekerabatan "angkatan". Seluruh kerabat yang berasal dari garis generasi yang sama, baik laki-laki maupun perempuan, saudara laki-laki maupun perempuan, atau sepupu, dimasukkan ke dalam kategori "saudara" (sumpung lolo, disebut juga seajing 'satu asal'). Sumpung berarti sambung (an), sedang lolo berarti usus atau hati. Kelompok kerabat dekat disebut seajing mareppe atau macawe' dan kelompok kerabat jauh disebut seajing mabela.

\section{Perkawinan}

Tujuan perkawinan pada masyarakat Bugis sama dengan masyarakat Makassar. Kalau orang Makassar mengatakan terhadap orang yang mau dikawinkan lanipattukmi ulanna salangganna, maka orang Bugis mengatakan elokni ri pakkalepu maksudnya akan diutuhkan, jadi orang yang belum kawin dianggap belum utuh. Bagi masyarakat Bugis, perkawinan berarti siala 'saling mengambil satu sama lain'. Jadi, perkawinan adalah ikatan timbal-balik. Walaupun mereka berasal dari status sosial berbeda, setelah menjadi suami istri mereka merupakan mitra." ${ }^{23}$ Dalam perkawinan masyarakat Bugis, laki-laki dan perempuan bukan hanya merupakansuatu kesatuan, namun mereka juga terikat menjadi satu kesatuan dengan keluarga masing-masing, baik

dari

pihak

laki-laki

maupun

perempuan.

Pernikahan menjadi sarana menyatukan antara dua keluarga bagi masyarakat Bugis. "Upacara penyatuan dan persekutuan dua keluarga dalam pernikahan biasanya telah memiliki hubungan sebelumnya dengan maksud kian mempereratnya. Di kalangan masyarakat biasa, perkawinan umumnya berlangsung antarakeluarga dekat atau antarakelompok patronasi yang sama. Perkawinan ideal pada masyarakat Bugis sama dengan masyarakat Makassar. Bahwa 
seorang laki-laki maupun wanita diharapkan untuk mendapatkan jodohnya dengan lingkungan keluarganya baik dari pihak ibu maupun dari pihak ayah. Berikut ini pernikahan yang ideal menurut masyarakat Bugis.

\section{Kesimpulan}

Sistem kekerabatan dalam suku bugis masih sangat mendalam dan masih menganut sisti assiajiang, Begitupun dengan perkawinan yang diselenggarakan oleh suku bugis, Masih sangat mengiikuti adat istiadat.

\section{Referensi}

Abdulsyani. Sosiologi Skematika, Teori dan Terapan. Jakarta: Bumi Aksara, 2002.

Abidin, Andi Zainal. Capita Selecta Kebudayaan Sulawesi Selatan. Ujung Pandang: Hasanuddin University Press, 1999.

Ardhani, Fitriah. "Perbedaan Kepuasan Perkawinan Pada Wanita

Suku Bugis, Jawa, Dan Banjar Di Kecamatan Balikpapan

Selatan Kota Balikpapan." eJournal Psikologi 3, Nomor 1 (2015): 358-368.

Badollahi, Muhammad Zainuddin "Struktur Kekerabatan dan Stratifikasi Sosial 'Bugis'.” Diakses 25 April 2018. https://www.kompasiana.com/muhammadzainuddinbadollahi/5 4f9479ca33311d33b8b5087/struktur-kekerabatan-danstratifikasi-sosial-bugis

Bakti, Andi Faisal Bakti. Diaspora Bugis. Makassar: Ininnawa, 2010.

Dahlan, H. M. "Prosesi Pemilihan Jodoh dalam Perkawinan:

Perspektif Ajaran Islam dan Budaya Lokal di Kabupaten

Sinjai." SOSIOHUMANIKA: Jurnal Pendidikan Sains Sosial dan Kemanusiaan 9, no. 1 (Mei 2016): 131-142.

Hesselgrave, David J. Communicating Christ Cross-Culturally. Malang: Literatur SAAT, 2013.

Kobong, Th. Iman dan Kebudayaan. Jakarta: BPK Gunung Mulia, 1977.

Lestari, Puji. Antropologi 2: Untuk SMA dan MA Kelas XII. Jakarta: Departemen Pendidikan Nasional, 2009.

Lingenfelter, Sherwood G. dan Marvin K. Mayers. Menggeluti Misi Lintas Budaya.

Jakarta: Yayasan Komunikasi Bina Kasih/OMF, 2008.

Maruki, H. M. Laica. Siri': Bagian Kesadaran Hukum Rakyat BugisMakassar (Sebuah Telaah Filsafat Hukum). Ujung Pandang:

Hasanuddin University Press, 1995.

Moein MG, A. Menggali Nilai Sejarah Kebudayaan Sulselra Siri' \& Pacce. Ujung Pandang: SKU Makassar Press, 1977. 
Pelras, Christian. Manusia Bugis. Jakarta: Nalar, 2006.

Proyek Penelitian dan Pencatatan Kebudayaan Daerah. Geografi Budaya Daerah Sulawesi Selatan. Jakarta: Balai Pustaka, 1977.

. Adat dan UpacaraPerkawinan Daerah Sulawesi

Selatan. Jakarta: Balai Pustaka, 1977.

Rahim, A. Rahman. Nilai-Nilai Utama Kebudayaan Bugis. Ujung

Pandang: Lembaga Penerbitan Universitas Hasanudin, 1985.

Jurnal Lembaga STAKN Kupang | MATHETEUO Vol. 6, No. 2, November 2018

174

Ridha, Muh. Rasyid. "Integrasi Orang Bugis Di Kabupaten Gowa

(Studi Sosiologi terhadap Orang Bugis Bone di Bollangi)."

Seminar Nasional "Pendidikan IImu-IImu Sosial Membentuk

Karakter Bangsa Dalam Rangka Daya Saing Global." Grand

Clarion Hotel, Makassar: Fakultas IImu Sosial Universitas

Negeri Makassar dan Himpunan Sarjana Pendidikan IImu-ilmu

Sosial Indonesia, 29 Oktober 2016. 